\section{Vienna to gain biology centre}

Vienna

THE University of Vienna announced last week its intention to build a Biozentrum in the city's third district. The centre will house five university institutes from the medical and science faculties.

The creation of the centre fulfils an informal promise that the Austrian government made to Genentech and Boehringer Ingelheim when those two companies decided to locate their Institute for Molecular Pathology (IMP) in Vienna. The two institutions will be adjacent and will share support facilities.

The Austrian government will pay about 300 million schillings ( $\$ 25$ million) for the Biozentrum, which will be ready for occupation in 1991. The project is an indication of the changing attitude of the government towards basic research under new Science and Education Minister Hans Tuppy. Tuppy is "the best thing that has happened to Austrian science", said Max Birnstiel, director of the IMP.

The university will endow two new chairs in general biochemistry and molecular genetics. Both positions should be filled in 1988, said Helmut Ruis of the general biochemistry department, with the professors working in existing university labs or at the IMP until the Biozentrum is completed.

Some junior faculty members have already been hired, including Rudolf Schwein in yeast genetics and Erwin Wagner in mouse developmental genetics. There will be five university institutes from both the medical and science faculties in the new centre.

The Biozentrum, "inspired by" the institution of the same name in Basel, Switzerland, should attract Austrian researchers thinking of returning from abroad as well as foreigners, said Ruis. "It has traditionally been hard to attract people with an international reputation to the University of Vienna", he said.

The IMP will make a difference. Director Birnstiel, who came from the University of Zurich to take the helm in 1986 (see Nature 321, 716; 1986), reported that the IMP has almost completed its staff and will move into its new quarters in January, 1988. The official opening of the IMP coincides with a meeting on "Genes in Control of Growth, Differentiation and Disease" to be held at the end of May 1988. The meeting may encourage other good researchers to consider moving to Vienna. But, Ruis warned, the situation may get "tricky" if the quality of research outstrips the money available for grants. It remains to be seen whether the infusion of new life in molecular biology is too little, too late.

Steven Dickman

\title{
Late Antarctic spring might be caused by ozone depletion
}

\section{Washington}

The Antarctic spring has arrived weeks later than at any time in the past thirty years, raising fears that the 'ozone hole' has begun to affect world climate.

Radiosonde data relayed directly from the British Halley Bay base reveals that the spring breakdown of the polar vortex - a circulating mass of very cold air that forms over the Antarctic during the long, dark winter - has been "very much delayed", according to Jonathan Shanklin of the British Antarctic Survey.

Normally, the vortex breaks up in late October or early November but this year it has remained until mid-December. Shanklin, one of the first researchers to detect the reduction in Antarctic ozone, suggests that there may be a direct relation between the late spring and the ozone hole. Ozone absorbs ultraviolet light and helps to heat up the atmosphere and break down the polar vortex; with so much less ozone the atmosphere warms more slowly.

The effect will tend to perpetuate itself.

\section{Global $\mathrm{CO}_{2}$ action}

\section{Washington}

IN the second year of trying, Senator Joe Biden (Democrat, Delaware) and others have succeeded in attaching an amendment to the current US State Department authorization bill that requires the Secretary of State to work towards concerted international action on the build-up of greenhouse gases in the Earth's atmosphere. The State Department must work with the Environmental Protection Agency to assess the concentrations of such gases, especially carbon dioxide, and the danger they pose, and to begin talks with other countries with the aim of establishing a global policy, perhaps modelled on the recent Montreal protocol for ozonedestroying pollutants.

Whereas chlorofluorocarbons have caused the Antarctic ozone hole, and acid raid has damaged forests, carbon dioxide has not yet been proved guilty of any demonstrable ills. Gathering a political force against it may thus be harder. Moreover, carbon dioxide is released as a direct consequence of combustion, not as a sideeffect, and reduction of emission demands policies to conserve energy and to develop alternative sources of power, both of which programmes have lost momentum now that oil is cheap again. But concern over global atmospheric change has been in the public mind lately, and supporters of Biden's amendment think the time is right for the United States to wield its influence. David Lindley
With a cold atmosphere, stratospheric cloud will be more likely to form and provide the right conditions for chemical reactions that further reduce ozone levels.

The immediate effect of the late breakup of the polar vortex will be limited to Antarctica. But the change is a major one in atmospheric circulation, and "it is likely that it will have consequential effects in the Southern Hemisphere generally", says Shanklin. Modellers will now be busy seeing if there are detectable effects on surface temperature distinguishable from normal variability.

The delayed spring breakup of the ozone hole means that Antarctic organisms will have spent longer exposed to higher-than-normal levels of ultraviolet light. What effect that might have on plankton and Antarctic food chains is unknown. Alun Anderson

\section{Leningrad tie with California}

\section{San Francisco}

OfFICIALs from Leningrad University last week visited the University of California (UC) to sign a three-year agreement for academic exchange.

Leningrad University, the Soviet Union's second-best university after Moscow, is known for its physical sciences and its energetic efforts to act as host to foreign scholars (see Nature 329, 796; 1987).

The programme, scheduled to begin in the summer or autumn of 1988 , provides for the exchange of up to 100 students, professors and researchers each year in the fields of mathematics, physics, language, sociology and education. The exchanges will range from 3 -week summer cultural visits for undergraduates to 30 month exchanges for researchers.

Both universities have active foreign exchange programmes. Leningrad University hosts hundreds of scholars annually, from 27 universities, mostly in Eastern bloc countries. Each year about 1,200 UC students study abroad, at 70 host institutions in 28 countries, and UC hosts about 300 foreign students annually at its campuses.

A UC spokesman said the impetus for the programme arose from the cultural accord signed during the 1985 US-Soviet summit in Geneva, which called for increased "contacts, exchanges and cooperation". The programme is the second between Soviet and US universities -- the State University of New York has been conducting academic exchanges with Moscow University since 1974.

Marcia Barinaga 